\title{
The Novel in Lesson Hours (Classrooms)
}

Gentiana Muhaxhiri MSc.

Assistant of Albanian literature at "University of Gjakova "Fehmi Agani" (PhD. candidate)

Prof. Ass. Dr Sindorela Doli-Kryeziu

professor of Albanian language at "University of Gjakova "Fehmi Agani"

Venera Muhaxhiri MSc.

Assistant at "University of Gjakova "Fehmi Agani"

\begin{abstract}
The novel as a complex fictitious form in which is projected the life totality has begun to lose new readers, with special emphasis on pre-university level. This study, through a survey conducted in the schools of the Republic of Kosovo, aims to show why and to what extent this phenomenon is manifested at the aforementioned level; How much and what is read; how is read. The recognition of new reader- novel reports, namely the recognition of the practical situation, becomes into the function of the possible solution of this problem that increases its magnitude day by day.
\end{abstract}

Keywords: Novel, the lesson hour, reading, reception

\section{Introduction}

By avoiding the exact language forms, with countless ways of presenting material, the novel is the art of projecting a different world; a possibility of escape from the reality of life; the ennoblement and the spiritual growth.

The general perception is that nowadays the novel has lost the reader, with particular emphasis on the new reader. Such a perception, generalized, reckless, not based on facts, or just starting from some indicators such as the fact that young people are constantly using technology, gives the impression that today none of the young people read novels. Certainly, there's a lot of truth regarding this conclusion. Nevertheless, impressions created in this form, without a real measurement, without a verification of the actual situation, are not convincing and as such cannot be taken for granted.

\section{Creating the new reader}

It would be called utopia if in this day and age we are looking forward to finding the old school reader. It is impossible that the rapid development of human society, which has influenced in every sphere of life, to not affect the reading process, at the time when life's dynamism grows more and more, reading the novel as the longest type of prose "takes a lot of time" of youngsters and is often overcome. "Unlike the lyricism and short form of prose or even drama, the novel is more open, more accumulative ... in its most prominent shows, the novel is a work in which the prose is transformed into poetry and poetry in prose"

Within a single work, the novel creates many realities that break away from a series of addictions and create their own artistic unity. Essential issues of the novel are treated as distinct categories, which are uniform enabling its receptors to select which to put on top.

Whether the novel remains a professional challenge for the literary scholar, no matter how skillful he or she is are demonstrated by several examples of " uncertainties", such as: novel is a multi-faceted genre, although there are important novels where the is one storyline, the novel is a love story, even though the highest models of the European novel are completely stripped of the element of love ... ". 
Therefore, the youngsters' reception of the novel is varied. It is not just the lack of willingness to read, but also the teacher's approach and expectations from the students. The teacher's expectations should be realistic, compatible with the abilities of his/her students. It cannot be expected of primary school pupils to deal with the comprehensive and specialized analysis of the novel when their knowledge of literary theory is limited, however the level of expectation should change to the pupils of secondary school, who have a higher level of knowledge of literature, and potentially, they can become future literature scholars. So, the ability of a teacher to adapt to his/her student's age skills is a good start, but it is not everything.

Prior to the teacher "presents" the novel, a long, circumstantial preparation is required. "Therefore, truth in art is neither limited nor standardized, as it is not true only for itself, because then it would be worthless and would not serve anyone." Modalities need to be found in order that students will be eagerly waiting to read a work of literature, "Since in the world of great art, there is always something to be discovered."

Unfortunately, the findings of many years ago are still valid: "As a first problem is our outdated education system of all levels, starting from elementary to university studies. If one can say that today's literature has gone through several stages of development, there have been major changes in all aspects thus creating a series of stylistic orientations and a large number of creative individualities, the methods of literature study have remained unchanging, have not followed the development of literature as a process that is transformed every day, but as a static subject once and for all. "This is also evidenced by the fact that during a survey conducted in the schools of the Republic of Kosovo, a significant number of teachers escaped the completion of a questionnaire concerning the way they teach the novel in the class. The number of teachers who filled the questionnaire simply "because they had to" is very large.

This happens when the teacher finds ways that awaken the students' curiosity, such as the proper handling of a novel fragment, especially when we want to encourage reading outside of the classroom, or finding appropriate methodology within the lecture, where it can be included the assigning of specific tasks for groups of students, analyzing the same element of the work from different perspectives, specifically tasks that are attractive to the particular ages and from which students can enrich their souls, as well as intellectual growth and development of aesthetic taste. But, how well prepared are teachers for this "task"?

\section{How much and how is read}

The results of the survey conducted at the end of the academic year 2016/2017 in schools show different levels of teachers' approach to the lessons of the novel, either with reading fragments or the novel as a whole. As a consequence, students' approach to the novel also changes.

To the question of what they read more: storybooks, novels or poetic volumes, it is noteworthy that the novel remains the most popular genre followed by the storybooks, while the poetic volumes, according to the results of this survey, are scarcely read.

Although the novel remains the most read genre, we cannot take this fact unreservedly, as teachers with their own approach, whether or not they have influenced the creation of semantic readers instead of working towards transforming readers from semantic to semiotic ones.

According to the survey, it is obvious that the number of novel readers is directly dependent on the requirements of the teacher. This is evidenced by the fact that even in schools of the same profile the number of novels read by students is significantly different in the classroom where the teaching is held by different professors. As far as the novel is concerned, it can be implied that the largest number of its readers are females. Certainly, this number is different in other cities, but what does not change is that the dominant reader of the novel is female. Thus e.g. in a professional school in Gjakova, the average of the novels read during a school year by students is 5.5, while in a professional school in Mitrovica the average number of novels read by females is 3.6. As for the number of male readers in these schools, the results of the study are as follows: in the first school 3.3 novels, whereas in the second school 2.3 novels read by a student during a school year.

Regarding the question whether they preferred the lectures where only fragments of novels are analyzed (these are included in the books of literature for high schools) or the novels as a whole (most of which relate to reading outside the classroom) the students have preferred the lectures where the novel is analyzed in its entirety. Even though this fact should be considered as a positive sign that the novel has its readers, it is still upsetting because a considerable number of students who were asked whether: The analysis of novels is written by themselves or taken from friends or taken from the internet, 
they responded that they get the analysis of novels ready from the internet. This implies that the reading is formal and the reader fails to dive deeply into the literary work, but lies on its surface, thus failing to capture its essential values. What leaves even more negative impression is the fact that teachers allow these issues to happen with countless students.

However, if students were to read only literary criticism from literary scholars, then the problem would be smaller, because at least they would face the real artistic and aesthetic values of the work for which they read, they would be acquainted with genuine criticism and would benefit from it. However, today on different Internet sites, almost everybody is able to post their own writings, no matter if they are worthless or not. A fair and serious approach by their teachers would prevent, at least in large part, this problem.

\section{Conclusion}

Based on the aforementioned survey, we conclude that reading novels by youngsters has not fallen to "zero level" as some claim, however it does not mean that it is on its best. If we rely on the average, it is noticeable that the novel could retain considerably its reader. What is worth mentioning is that this average is increased by the number of novels that are read by some students who claim to have read over 15 novels during a school year. Therefore, we can speak about different cases, students who read a lot, those who read a bit and those who do not read at all.

Since literature books include an enormous number of novels, it is teachers' "fault" for the decrease of the avid reader; many of the teachers are not considering the fact that a small mistake will be the cause of pushing away readers rather than attracting new ones to read novels. Therefore, teachers should provide the quantity and the quality of reading, include elements of novelty into classroom, provide adequate study methods, and be vigilant regarding plagiarism. Harmonizing these elements would lead towards the creation of a new dimension of novel reception by young people.

\section{References:}

[1] Bahtin,M., Çështje të romanit, Rilindja, Prishtinë, 1980.

[2] Bashota, S., Domethënia e ideve letrare, Rilindja, Prishtinë, 2001

[3] Bloom, Harold, Si dhe pse të lexojmë, Dudaj, Tiranë, 2008

[4] Çezarini Mertineli, Lucia, Filologjia, Medaur

[5] Elsie, Robert, Histori e letërsisë shqiptare, Dukagjni, Pejë, 2001

[6] Gashi, Osman, Kufijtë e letërsisë, Rozafa, Prishtinë, 2008

[7] Jakllari, Adem, Leksione për antropologjinë kulturore, SHBLU,Tiranë, 2010

[8] Krasniqi, Bajram, Letërsia dhe vetëdija historike, Rilindja, Prishtinë, 1984

[9] Musai, B. Metodologii e mësimdhënies, Albgraf, 2013

[10] Pettijohn,Terry F. Psikologjia nje hyrje koncize, Tiranë, 1996

[11] Solar, Milivoj, Hyrje në shkencën për letërsinë, Julvin2, Tiranë, 2004 (përsht. Floresha Dado)

[12] Welek, Rene \& Warren, Austin, Teoria e letërsisë, Onufri, Tiranë,2007 